\title{
New species in the genus Muelleria (Bacillariophyta) from the Maritime Antarctic Region
}

\author{
Bart VAN DE VIJVER ${ }^{1,2}$, Ralitsa Zidarova ${ }^{3} \&$ Kateřina KopalovÁ ${ }^{4}$
}

\author{
${ }^{1}$ Botanic Garden Meise, Department of Bryophyta \& Thallophyta, Domein van Bouchout, B-1860 Meise, \\ Belgium; *Corresponding author e-mail:vandevijver@brfgov.be \\ ${ }^{2}$ University of Antwerp, Department of Biology, ECOBE, Universiteitsplein 1, B-2610 Wilrijk, Belgium \\ ${ }^{3}$ Department of Botany, Faculty of Biology, St. "Kliment Ohridski" University of Sofia, 8 Dragan Tzankov Blvd., \\ Sofia 1164, Bulgaria \\ ${ }^{4}$ Department of Ecology, Faculty of Science, Charles University in Prague, Viničná 7, CZ-128 44 Prague 2, \\ Czech Republic
}

\begin{abstract}
During a survey of the freshwater aquatic and limno-terrestrial diatom flora of the Maritime Antarctic Region, six taxa belonging to the genus Muelleria that could not be identified were observed. Based on detailed LM and SEM observations, these six taxa have been described as new taxa: Muelleria desseiniana sp. nov., M. levkoviana sp. nov., M. nogae sp. nov., M. spauldingiana sp. nov., M. subsabbei sp. nov. and $M$. undulatoides sp. nov. Comments are made on their taxonomic position and how they can be distinguished from other species in this genus. Brief notes on the ecology and distribution of the six taxa are added. A compiled list of all Muelleria taxa described worldwide is included in this paper.
\end{abstract}

Key words: Antarctic Region, morphology, Muelleria, new species, taxonomy

\section{INTRODUCTION}

The genus Muelleria is one of the most species rich genera in the Antarctic Region despite its rather low total number of described species (Spaulding et al. 1999; VAN DE ViJVer et al. 2010). Up to now, only 29 taxa are recognized worldwide of which 16 have a distribution restricted to the Antarctic Region. Table 1 summarizes all collated published taxonomic information on all Muelleria species described so far worldwide. Together with the genera Diadesmis, Luticola and Hantzschia, the genus is one of the major constituents of the terrestrial (soil) diatom flora, although populations rarely reach high abundances (Fermani et al. 2007; Kopaloví \& Van De Vijver 2013). VAN DE VIJVER et al. (2010) elaborately discuss the success of the genus Muelleria in the Antarctic Region which may be due to several factors such as their strong preference for wet or semidry terrestrial habitats which are abundantly present in this region. But it is also likely that a comparable diversity within this genus could be found in the Arctic Region and the low number of recorded taxa from the Arctic could be the result of undersampling and/or force-fitting.

Muelleria taxa are easily recognizable in light microscope (LM) based on the presence of longitudinal ribs bordering the axial area, typically (strongly) deflected to even hooked proximal raphe endings and central striae that are usually more distant than the other striae in most species. Confusion with other taxa is only possible with certain species of the genus Neidium but the latter is very rare in the Antarctic Region (HamiLton et al. 2013).

The highest Muelleria diversity seems to be concentrated on the South Orkney (SOI) and South Shetland (SSI) Islands. Spaulding et al. (1999) and VAN DE VIJVER et al. (2010) described nine new taxa from Signy Island (SOI), Deception Island (SSI) and King George Island (SSI). During an ongoing revision of the Antarctic diatom flora of some islands in the Maritime Antarctic Region, several very small populations of Muelleria taxa were found on Livingston Island (SSI) and James Ross Island. Based on LM and SEM analysis of their structure, six of these taxa could not be identified using the currently available literature and are described here as new species. The relationship of the new taxa in comparison with other Muelleria taxa from the Antarctic Region and notes on their ecological preferences are presented.

\section{Materials ANd Methods}

Epilithic, sediment and moss samples were collected from various terrestrial and freshwater habitats in the following islands in the southern Atlantic Ocean: Livingston Island (South Shetland Islands) and James Ross Island (Table 1). Samples were fixed in the field with 3\% formaldehyde. More information on sampling methods and physico-chemical 
Table 1. List of samples and their characteristics used in this paper.

\begin{tabular}{|c|c|c|c|c|}
\hline Sample & Collection date & Locality & GPS coordinates & Short description \\
\hline JRI-S1J & $22 / 02 / 2007$ & $\begin{array}{l}\text { Komárek's slopes below } \\
\text { Berry Hill, Ulu Peninsula, } \\
\text { James Ross Island }\end{array}$ & (not determined) & seepage area \\
\hline $5-1 / 05$ & $08 / 01 / 2005$ & $\begin{array}{l}\text { Hurd Peninsula, Livingston } \\
\text { Island, South Shetland } \\
\text { Island }\end{array}$ & (not determined) & $\begin{array}{l}\text { wet terrestrial mosses } \\
\text { on the edge of a pool }\end{array}$ \\
\hline BYM008 & $9 / 01 / 2009$ & $\begin{array}{l}\text { Byers Peninsula, Livingston } \\
\text { Island (South Shetland } \\
\text { Islands, large plain near } \\
\text { large penguin rookery }\end{array}$ & (not determined) & $\begin{array}{l}\text { wet, terrestrial mosses } \\
\text { on edge of large lake }\end{array}$ \\
\hline BY052 & $15 / 01 / 2009$ & $\begin{array}{l}\text { Byers Peninsula, Livingston } \\
\text { Island (South Shetland } \\
\text { Islands, between Midge \& } \\
\text { Limnopolar Lake }\end{array}$ & $\begin{array}{l}62^{\circ} 38^{\circ} 20.1^{\prime \prime} \mathrm{S} \\
61^{\circ} 06^{\circ} 44.2^{\prime \prime} \mathrm{W}\end{array}$ & $\begin{array}{l}\text { large lake with } \\
\text { algal mats and fine } \\
\text { sediment/sand on } \\
\text { bottom }\end{array}$ \\
\hline LIV-BY16A & $16 / 12 / 2006$ & $\begin{array}{l}\text { Byers Peninsula, Livingston } \\
\text { Island (South Shetland } \\
\text { Islands, close to the main } \\
\text { plateau }\end{array}$ & $\begin{array}{l}62^{\circ} 40^{\circ} 11.3^{\prime “} \mathrm{~S} \\
61^{\circ} 08^{\circ} 45.3^{\circ " \mathrm{~W}}\end{array}$ & $\begin{array}{l}\text { biofilm in a flooded } \\
\text { area between stones }\end{array}$ \\
\hline LIV-BY16C & $16 / 12 / 2006$ & $\begin{array}{l}\text { Byers Peninsula, Livingston } \\
\text { Island (South Shetland } \\
\text { Islands, close to the main } \\
\text { plateau }\end{array}$ & $\begin{array}{l}62^{\circ} 40^{‘} 11.3^{\prime \prime} \mathrm{S} \\
61^{\circ} 08^{\circ} 45.3^{\prime \prime} \mathrm{W}\end{array}$ & $\begin{array}{l}\text { biofilm in a flooded } \\
\text { area between stones }\end{array}$ \\
\hline
\end{tabular}

analyses can be found in Kopalová \& VAN DE ViJVer (2013) and Kopaloví et al. (2013).

For light microscope (LM) observations, diatom samples were prepared following the method described in VAN DER WERFF (1955). In total, 6 sample sites and microhabitats were examined in this study, with all samples listed in Table 2. Subsamples of the original material were oxidized using $37 \% \mathrm{H}_{2} \mathrm{O}_{2}$ and heating to $80{ }^{\circ} \mathrm{C}$ for about $1 \mathrm{~h}$. The reaction was further completed by the addition of saturated $\mathrm{KMnO}_{4}$. Following digestion and centrifugation (three times $10 \mathrm{~min}$ at $3700 \times \mathrm{g}$ ), the material, free of organic matter, was further diluted with distilled water for sample mounting to avoid excessive concentrations of diatom valves on the slides. A subsample from the organic-free material was mounted in Naphrax ${ }^{\circledR}$. The slides were analyzed using an Olympus BX51 microscope, equipped with differential interference contrast (DIC) optics (Nomarski) and Colorview I Soft Imaging System. Observations on Muelleria levkoviana sp. nov. were made using brightfield optics as images in DIC produced only overexposed images. Diatom samples and slides are stored at BR (National Botanic Garden of Belgium). For scanning electron microscopy (SEM), aliquots of the oxidized suspensions were filtered through 1$\mu \mathrm{m}$ pore size polycarbonate filters which were cut in small pieces, fixed on aluminum stubs after air-drying and sputter coated (Cressington 208HR, Watford, UK) with $\mathrm{Au}(10 \mathrm{~nm})$. Observations and photomicrographs were performed with a Zeiss ${ }^{\circledR}$ Ultra plus SEM at $8 \mathrm{kV}$ at the Natural History Museum (London, UK). The number of observations is quite low but can be explained by the very rare occurrence of Muelleria taxa in the different samples as was indicated previously in VAN DE VIJVER et al. (2010).

Identifications and species determinations are based primarily on Spaulding \& Stoermer (1997), Spaulding et al. (1999), Esposito et al. (2008) and VAN DE ViJVER et al. (2010). Terminology follows mostly VAN DE VIJVER et al. (2010) except for valve outline terminology that is based on HENDEY (1964) and raphe morphology that follows Round et al. (1990).

A compiled list of all Muelleria taxa known to date with references to their original description, type locality and presence in Antarctica is done (Table 2).

\section{Results AND Discussion}

A total of fourteen Muelleria taxa has been found in the samples. Eight of them had been previously described (Spaulding et al. 1999; VAN de ViJVer et al. 2010): $M$. aequistriata $\mathrm{VAN}$ DE VIJVER et S.A.SPAUlding, M. algida S.A.Spaulding et Kociolek, $M$. kristinae VAN DE ViJVER, $M$. regigeorgiensis VAn de ViJVer et S.A.SPAulding, $M$. 
rostrata VAN DE VIJVER \& S.A.SPAULDING, M. sabbei VAN DE ViJver et S.A.Spaulding, M. tumida VAN DE ViJVer et S.A.Spaulding and $M$. variolata S.A.SPAulding et Kociolek. Six taxa could not be identified using the currently available literature. All taxa were extremely rare in the samples making observations in LM and SEM quite difficult. Often only one (sometimes even damaged or broken) valve could be observed in SEM and internal views were very hard (and even impossible) to find. Nevertheless, a sufficient amount of observations, both in LM and SEM could be made to justify their description as new for science: Muelleria desseiniana sp. nov., M. levkoviana sp. nov., M. nogae sp. nov., M. spauldingiana sp. nov., M. subsabbei sp. nov. and M. undulatoides sp.nov.

\section{Muelleria desseiniana sp. nov. (Figs 1-10)}

Light microscopy (Figs 1-8): Frustules in girdle view rectangular (Fig. 1). Valves linear with gibbous central part and broadly rounded ends (Figs 2-8). Valve dimensions $(\mathrm{n}=10)$ : length $32-40 \mu \mathrm{m}$, valve width 8.5-10.0 $\mu \mathrm{m}$. Axial area rather narrow, linear, slightly widening near the small, elliptical central area. First row of areolae along the axial area separated from the remaining areolae by very narrow, but distinct hyaline line. Raphe filiform, straight with clearly unilaterally bent, long proximal raphe endings extending almost till
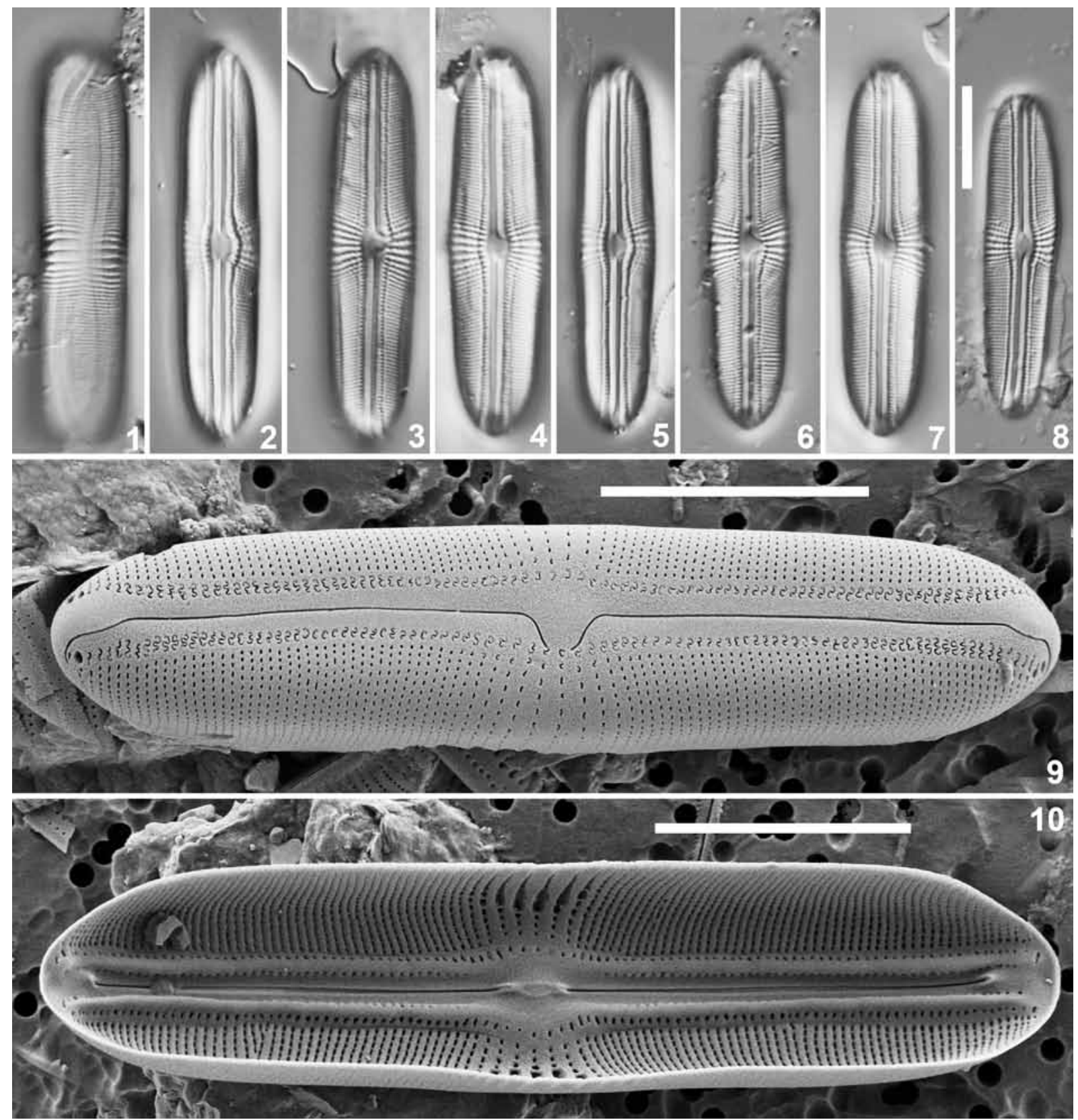

Figs 1-10. Muelleria desseiniana, type population from James Ross Island (sample JRI-S1J): (1-8) LM views; (9) SEM external view; (10) SEM internal view. Scale bar $10 \mu \mathrm{m}$. 


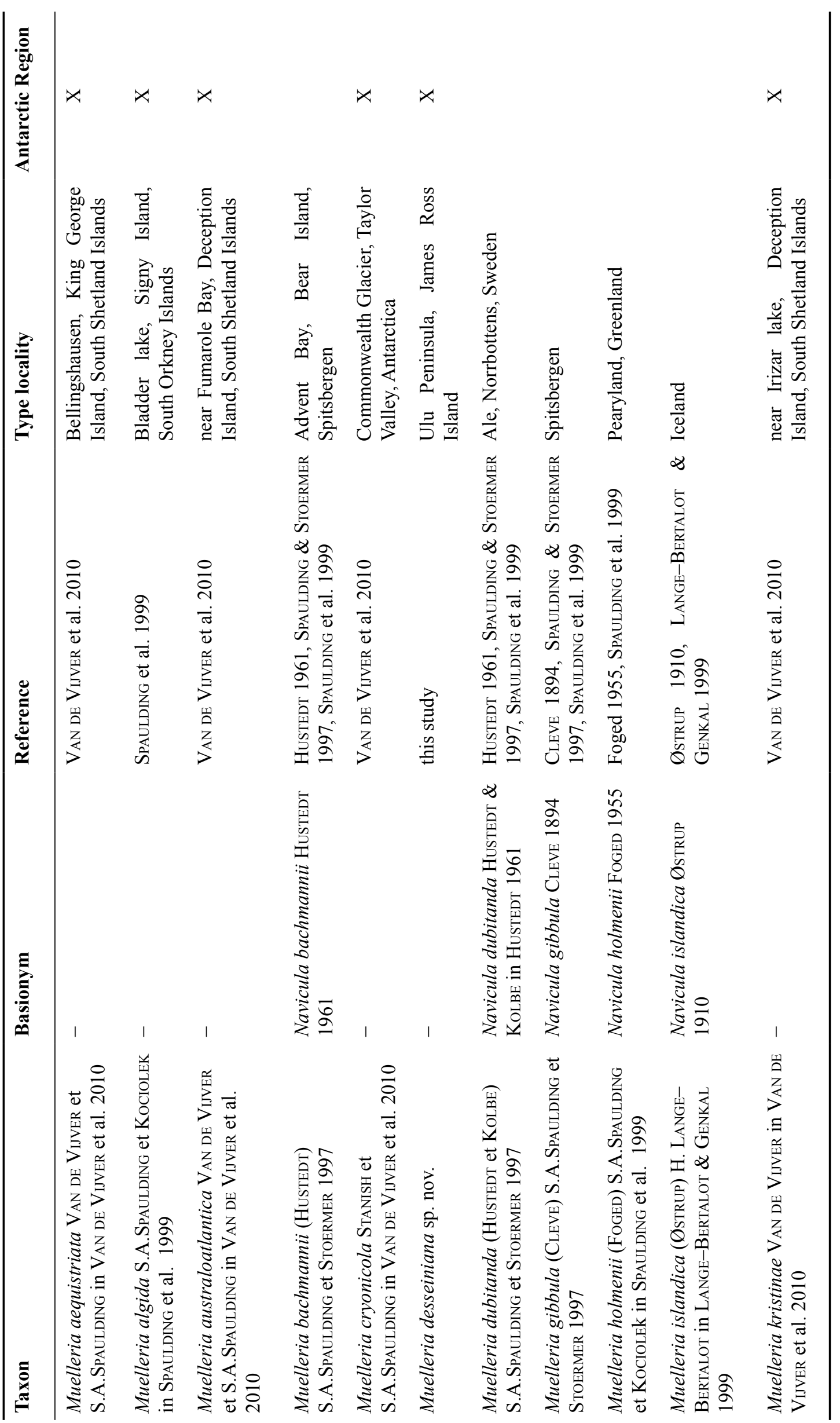




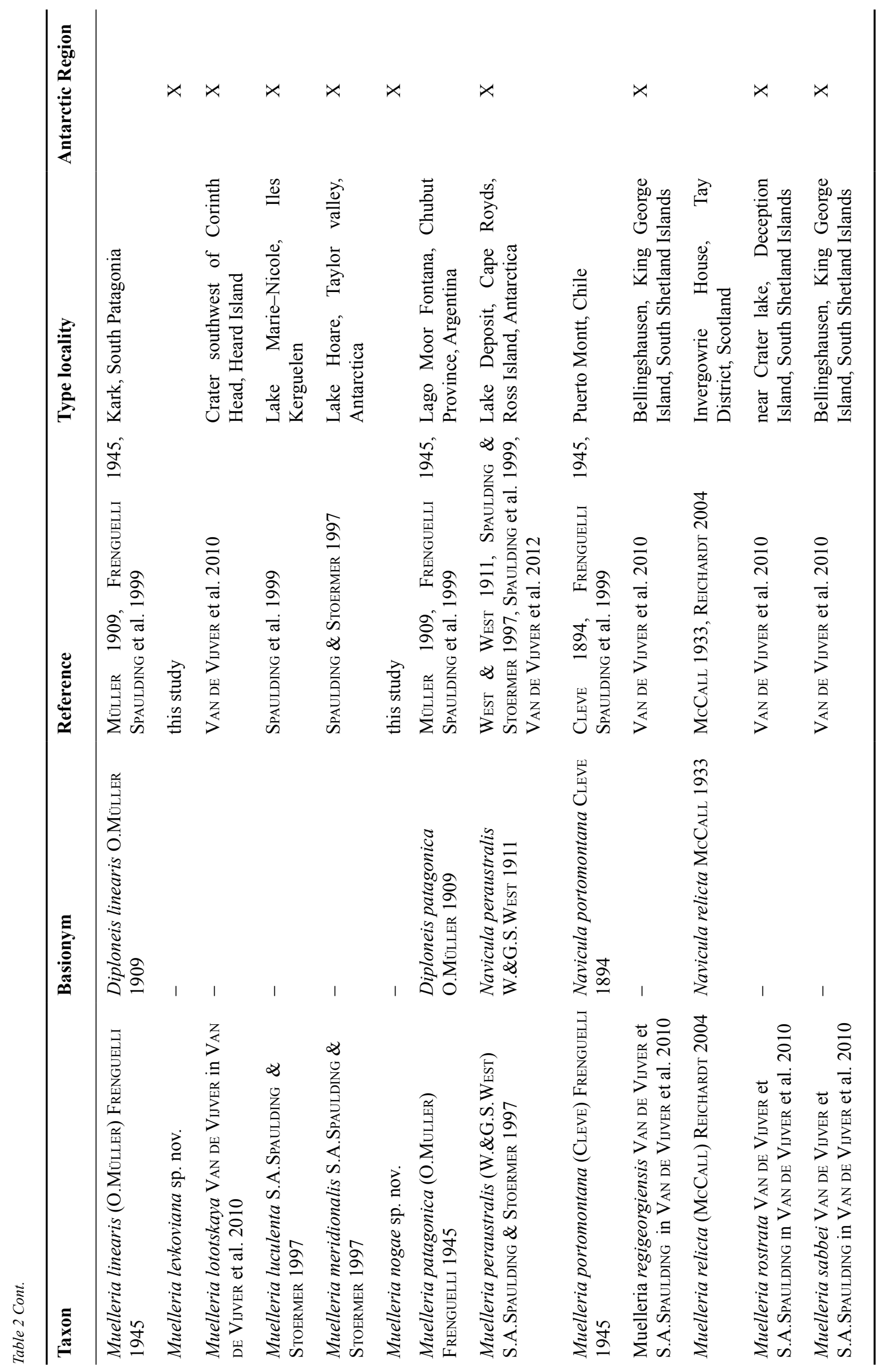




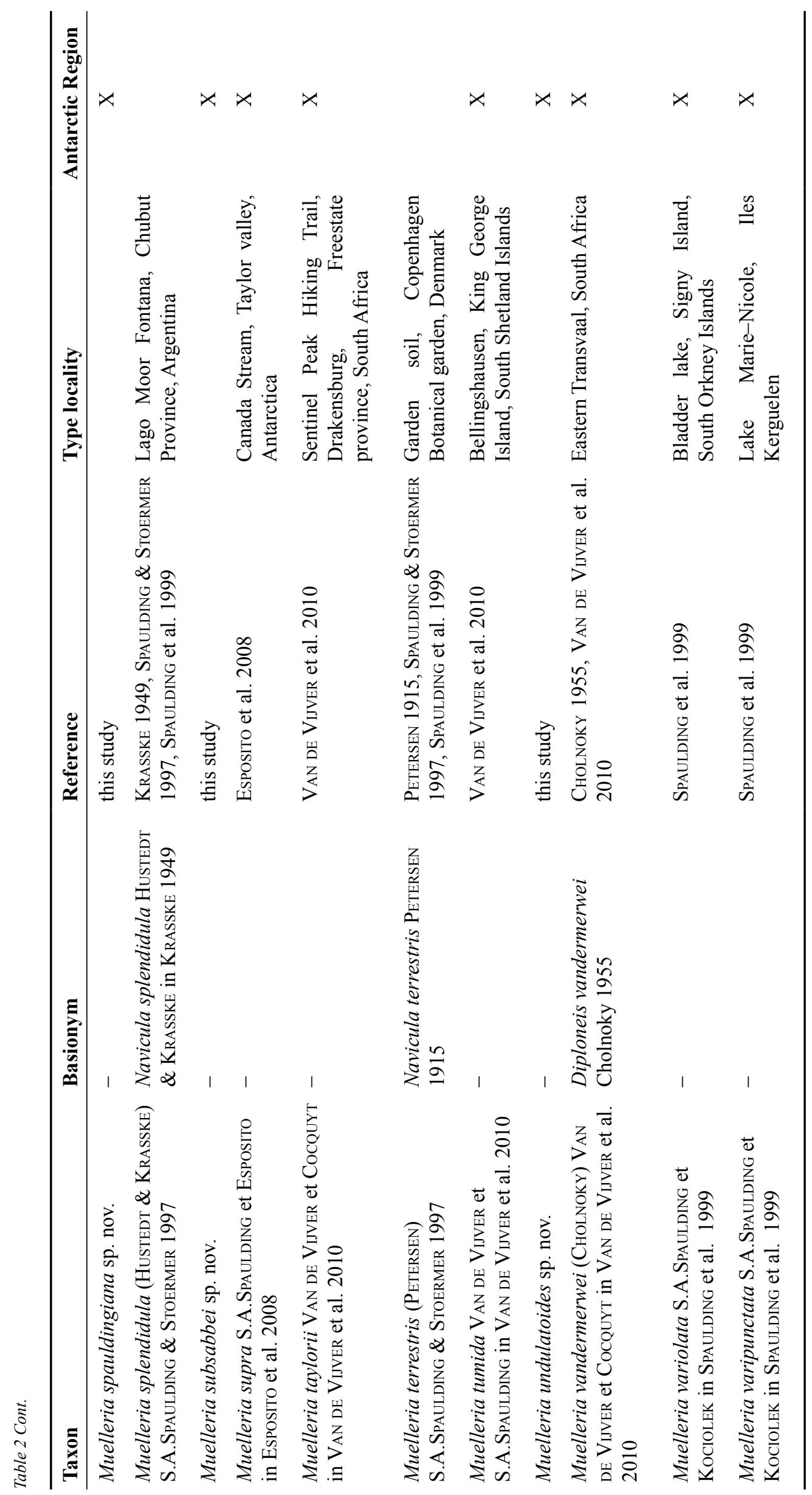




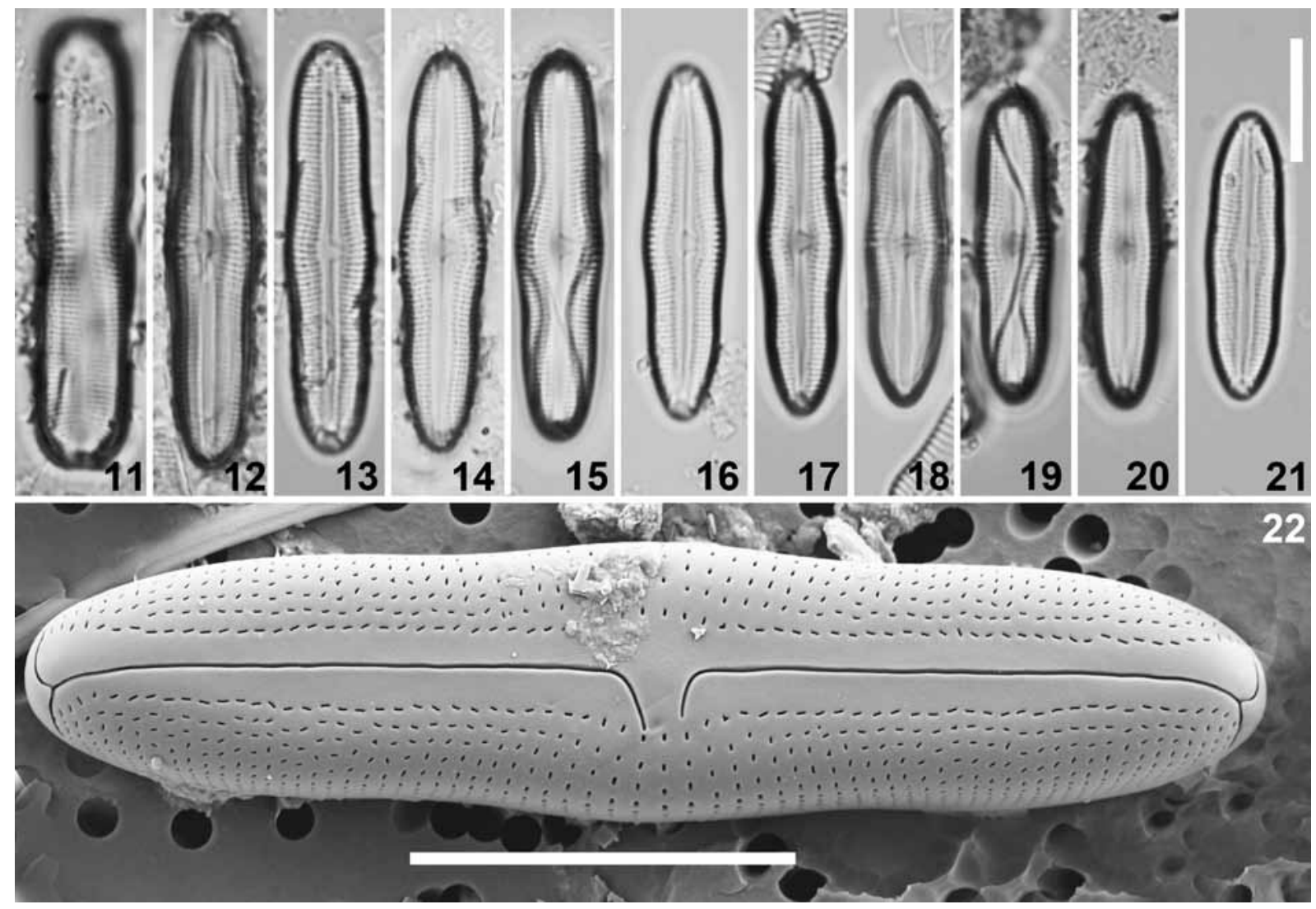

Figs 11-22. Muelleria levkoviana, type population from Livingston Island (sample BYM008): (11-21) LM views; (22) SEM external view. Scale bar $10 \mu \mathrm{m}$.

and even beyond the first row of areolae. Distal raphe endings are weakly deflected to the same side of the valve as the proximal raphe ends. Striae near the central area (6-9 striae) more spaced than the other striae and clearly radiate whereas other striae more distant from the central area only slightly radiate, becoming almost entirely parallel near the apices. Central striae 13-15 in $10 \mu \mathrm{m}$, distal striae $27-29$ in $10 \mu \mathrm{m}$. Areolae hardly discernible in LM.

Scanning electron microscopy (Figs 9-10): Striae composed of usually transapically elongated, short, slitlike areolae. First row of areolae bordering the axial area however appearing as short wavy slits, separated from the rest of the striae by a narrow hyaline area and gradually becoming longer towards the apices (Fig. 9). Near the distal raphe ends, one or two large, rounded canal punctae present. Proximal raphe endings unilaterally bent, long, extending into the first row of areolae. Distal raphe endings deflected onto the valve mantle, not bifurcated (Fig. 9). Internally, clear but short rectelevatum present between proximal raphe endings. Longitudinal canals forming narrow ribs running from central area towards the apices, clearly perforated on both sides by first row of areolae (Fig. 10). Distal raphe endings terminating on short helictoglossae (Fig. 10).

Holotype (designated here): BR-4350 (National Botanic Garden, Meise, Belgium)
Isotypes (designated here): PLP-244 (University of Antwerp, Belgium), BRM-ZU9/37 (Hustedt Collection, Bremerhaven, Germany)

Type locality: Ulu Peninsula, James Ross Island, sample JRI-S1J (Leg. J. Komárek; coll. date 22/02/2007).

Etymology: The species is named after our colleague Dr. Steven Dessein, director of the National Botanic Garden of Belgium in recognition of his scientific achievements in botany.

Ecology and distribution: So far the species was only observed in very small numbers in samples obtained from Livingston Island (SSI) and James Ross Island. The largest population was found in one sample, collected from a seepage area near Berry Hill on Ulu Peninsula on James Ross Island. The sample was dominated by several Luticola and Hantzschia species clearly indicating its aerophilic nature. Due to confusion with other similar taxa such as M. luculenta (as it was earlier reported in Zidarova 2008, Pl. III, fig. 26) or the larger and coarser $M$. algida, its geographic distribution is still unclear but it is not excluded that the new species is more widespread on the Maritime Antarctic islands.

Taxonomical remarks: Muelleria desseiniana has a unique combination of features that separates it 


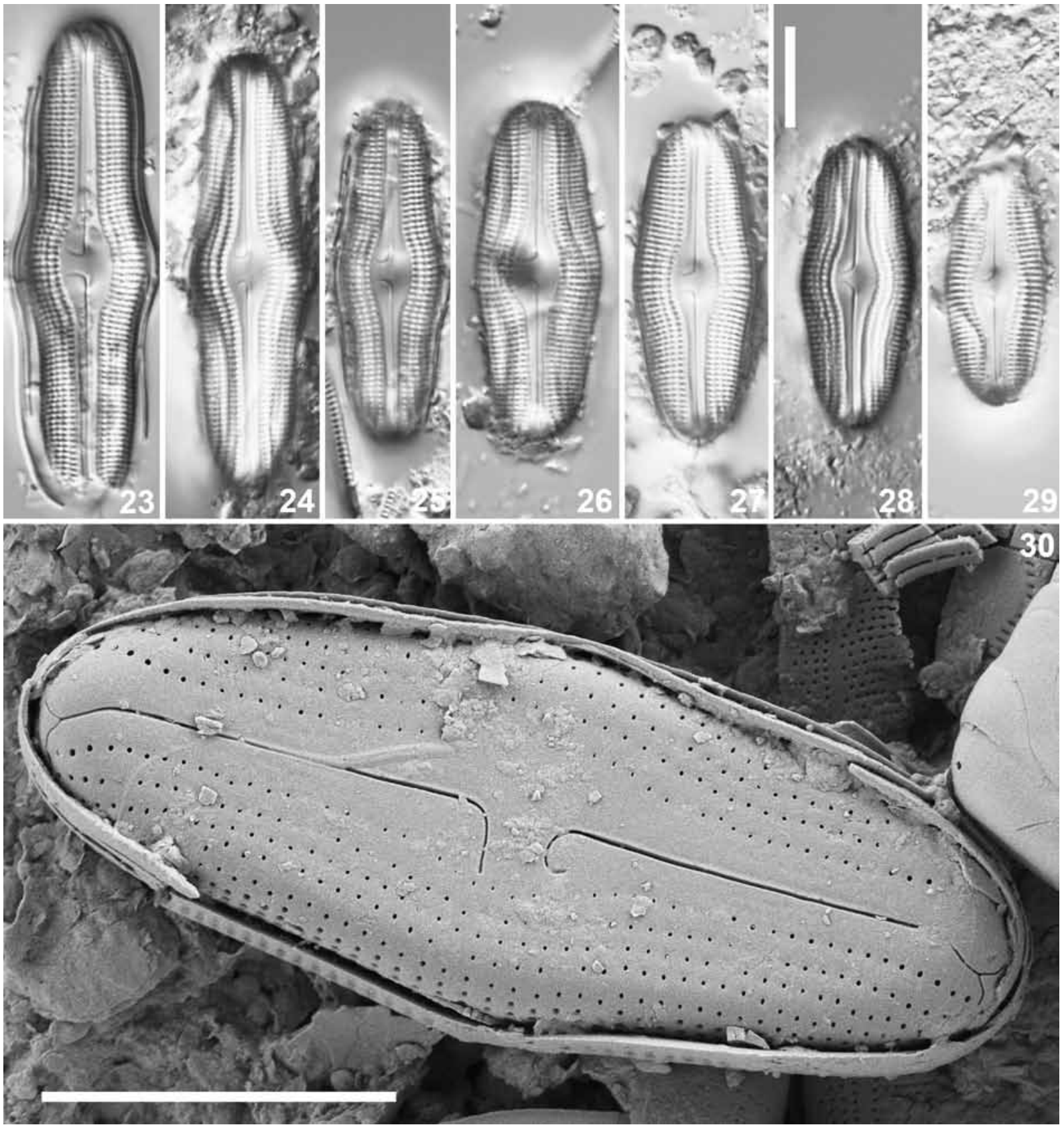

Figs 23-30. Muelleria nogae, type population from Livingston Island (sample LIV-BY16A): (23-29) LM views; (30) SEM external view. Scale bar $10 \mu \mathrm{m}$.

well from all other known Muelleria taxa. The raphe is not bifurcated in its distal part, a feature rarely seen within the genus Muelleria. Muelleria sabbei shows comparable, though shorter, raphe endings but has a clearly elliptic-lanceolate valve outline with broad, convex margins (VAN DE VIJVER et al. 2010). Additionally, the areolae bordering the central area are small and rounded whereas in M. desseiniana, the areolae form long wavy slits. Muelleria varipunctata S.A.Spaulding et Kociolek shows a similar valve outline but has a much coarser striation pattern, large round areolae near the axial area and different (=bifurcating) distal raphe endings. Muelleria lototskayae VAN DE VIJVER, M. luculenta and $M$. algida are larger with longer valves and a different raphe course, usually showing a terminal bifurcation (Spaulding et al. 1999; VAn DE ViJver et al. 2010). All three taxa have small, rounded to short slitlike areolae, never showing the elongated, wavy areolae typical for M. desseiniana.

\section{Muelleria levkoviana sp. nov. (Figs 11-22)}

Light microscopy (Figs 11-21): Frustules in girdle view rectangular (Fig. 11). Valves linear with clearly undulating margins, a gibbous central part and cuneately rounded ends (Figs 12-21). Valve dimensions $(\mathrm{n}=15)$ : length $24-38 \mu \mathrm{m}$, valve width 

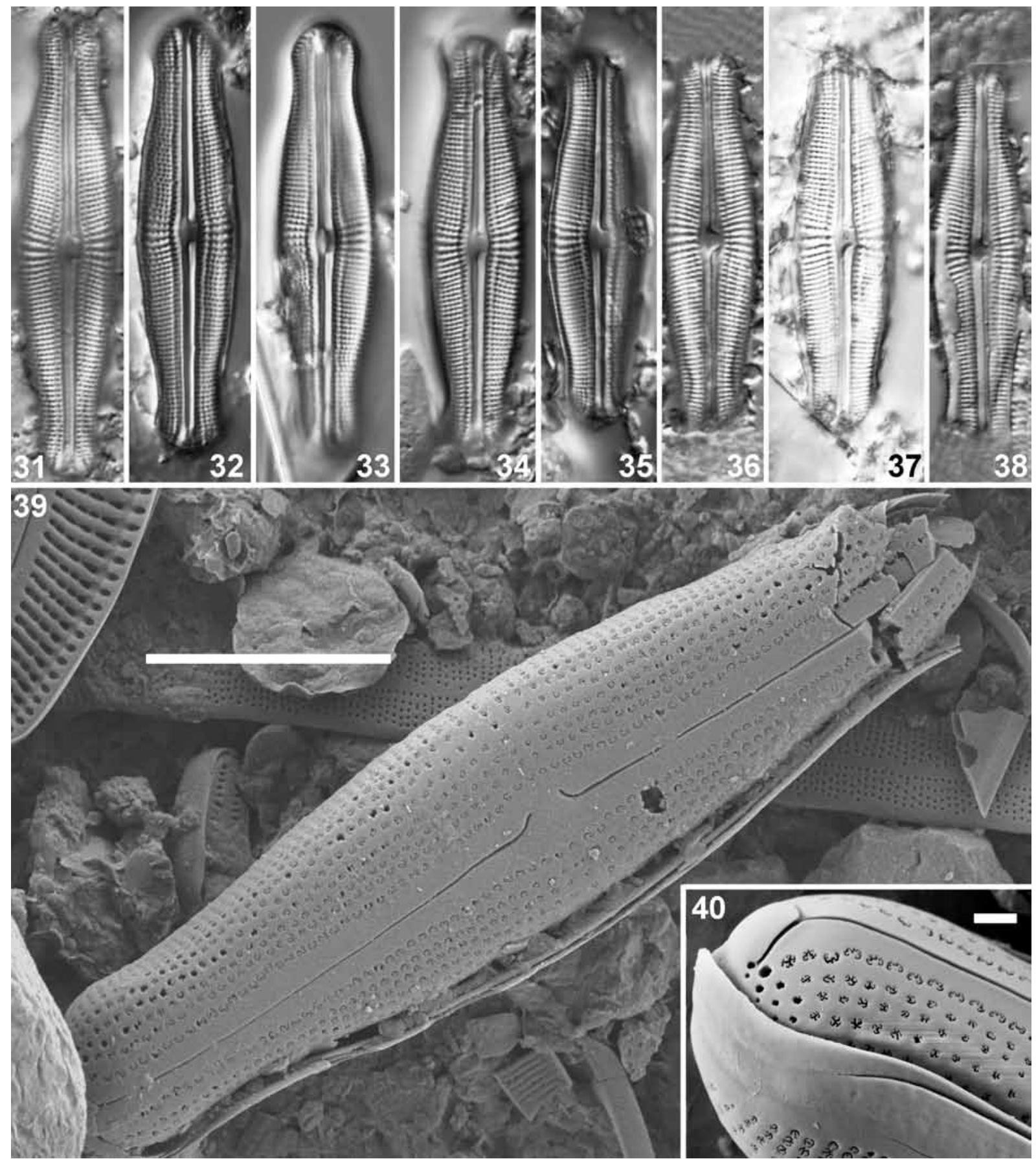

Figs 31-40. Muelleria spauldingiana, images from various population from Livingston Island: $(31,32,36)$ are from the type population (sample BY052); (31-38) LM views; (39) SEM external view of an entire (broken) valve; (40) SEM external detail of the valve apex in girdle view showing distal raphe fissures, mantle areolae and canal puncta. Scale bar $10 \mu \mathrm{m}(39), 1 \mu \mathrm{m}(40)$.

6.0-7.8 $\mu \mathrm{m}$. Axial area rather narrow, linear, widening near the small central area. First row of areolae not separated from the rest of the striae. Raphe filiform, straight with clearly unilaterally bent, long proximal raphe endings extending almost till and even beyond the first row of areolae. Distal raphe endings not well visible in LM, apparently deflected. Striae near the central area (5-7 striae) only slightly more spaced than the other striae and clearly radiate whereas other striae more distant from the central area only slightly radiate, gradually becoming parallel near the apices. Central striae $16-18$ in $10 \mu \mathrm{m}$, distal striae $20-22$ in $10 \mu \mathrm{m}$. Areolae moderately discernible in LM.

Scanning electron microscopy (Fig. 22): Striae composed of two types of areolae: near the axial area usually 1-3 rows of apically elongated areolae, gradually becoming transapically elongated. Central striae composed of only transapically elongated areolae. Proximal raphe endings clearly bent, almost reaching each other at the end, extending till the first 


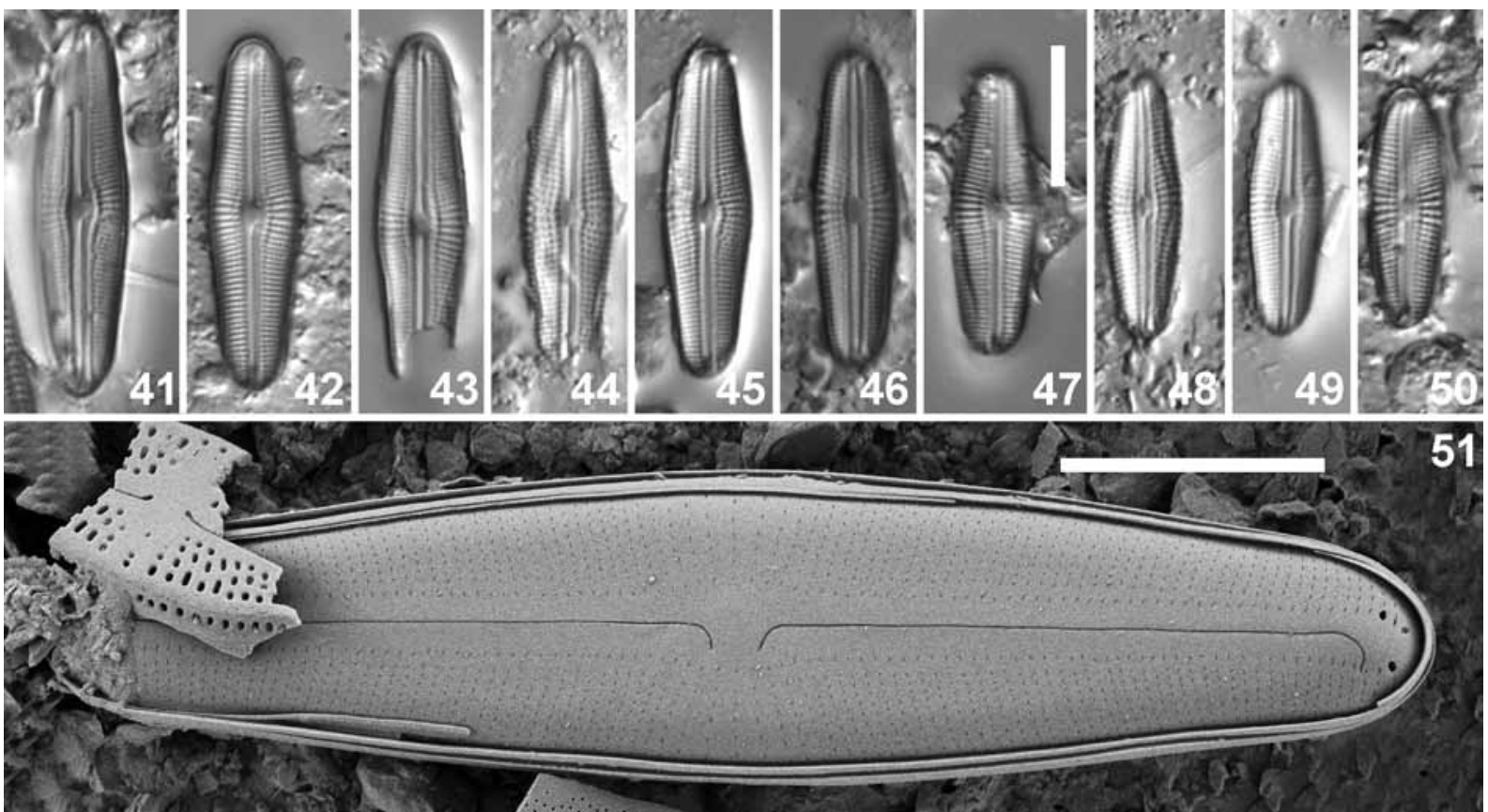

Figs 41-51. Muelleria subsabbei, type population from Livingston Island (sample LIV-BY16C): (41-50) LM views; (51) SEM external view. Scale bar $10 \mu \mathrm{m}$.
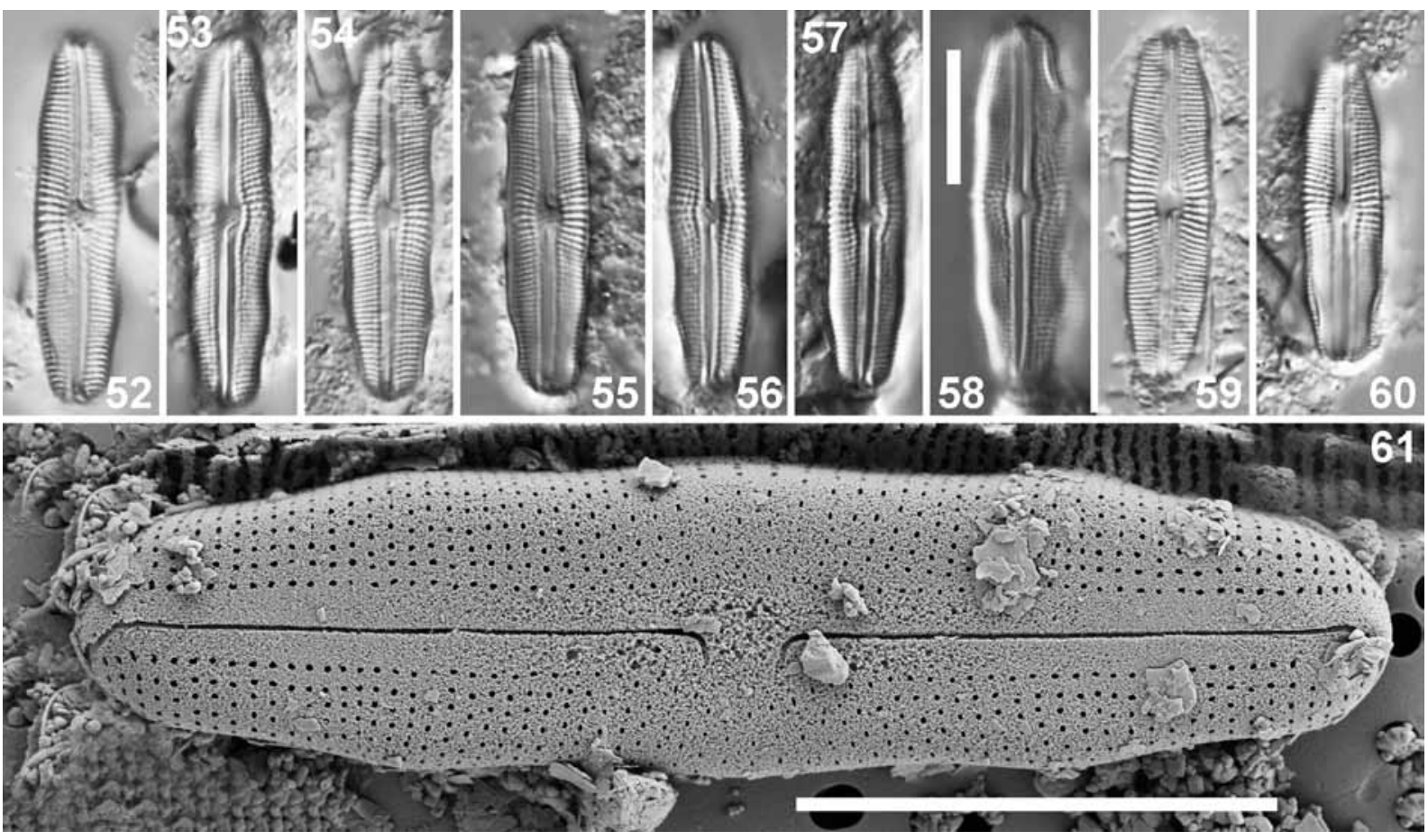

Figs 52-61. Muelleria undulatoides, type population from Livingston Island (sample 5-1/05): (52-60) LM views; (61) SEM external view. Scale bar $10 \mu \mathrm{m}$

row of areolae. Distal raphe endings deflected, clearly bifurcating due to siliceous flap. Canal puncta not observed. No observations of the valve interior could be made due to the rarity of the taxon.

Holotype (designated here): BR-4351 (National Botanic Garden, Meise, Belgium)
Isotypes (designated here): PLP-245 (University of Antwerp, Belgium), BRM-ZU9/38 (Hustedt Collection, Bremerhaven, Germany)

Type locality: Byers Peninsula, Livingston Island, South Shetland Islands, sample BYM008 (Leg. B. Van de Vijver; coll. date 09/01/2009).

Etymology: The species is named after our colleague 
Dr. Zlatko Levkov (University of Skopje, Macedonia) in recognition of his important contributions in diatom research.

Ecology and distribution: Muelleria levkoviana was only found so far in small numbers in one moss sample on Byers Peninsula (Livingston Island). The mosses were sampled near the shore of a very large lake close to a large penguin rookery. Remains of penguins, such as feathers and partly decomposed body parts, were visible in and around the lake. The sample was dominated by Chamaepinnularia australomediocris (LANGE-BERTALOT et SCHMIDT) VAN DE ViJver and various Psammothidium taxa such as $P$. papilio (Kellogg et al.) Kopalová et VAN DE ViJver, $P$. germainii (MANGUIN) SABBE and $P$. incognitum (Krasske) Van de Vijver et Beyens.

Taxonomical remarks: Despite the single SEM observation of the $M$. levkoviana so far, it is possible to justify its separation from all other Muelleria taxa known so far. Similar taxa include $M$. terrestris (Petersen) S.A.Spaulding et StOermer, $M$. meridionalis S.A.SPAULding et STOERMER, M. supra S.A.SPAUlding et Esposito, M. australoatlantica and M. relicta (MCCALL) REICHARDT. Muelleria relicta is probably the most similar species based on the structure of the central striae which are only weakly more distant in comparison with the rest of the striae. A similar pattern is found in M. levkoviana. Both taxa have a comparable raphe structure but differ in the valve outline with $M$. relicta having less undulating valve margins and more broadly rounded apices (McCALl 1933; ReICHARDT 2004). Moreover, based on the illustration in REICHARDT (2004, plate 4, fig. 7) it is obvious that the first row of areolae is separated from the rest of the striae contrary to M. levkoviana. It is however unfortunate that no SEM illustrations exist of M. relicta to allow comparison of the areola shape and the structure and the presence of canal puncta, absent in M. levkoviana. Muelleria supra has more undulating valve margins, a larger central valve part, more distantly spaced central striae and typically large canal puncta (Esposito et al. 2008). Muelleria terrestris is smaller with parallel valve margins while $M$. meridionalis has non-bifurcating distal raphe endings and two large canal puncta. Moreover, the areolae are large and rounded and never present the typical direction shift as is typical for M. levkoviana (SPAULDING et al. 1999). Finally, M. australoatlantica has larger central striae, longer proximal raphe endings and a high number of canal puncta and non-bifurcating raphe endings (VAN DE VIJVER et al. 2010).

\section{Muelleria nogae sp. nov. (Figs 23-30)}

Light microscopy (Figs 23-29): Larger valves linear with a clearly widened, gibbous central part and broadly rounded apices (Figs 23-24). Smaller valves more elliptic-lanceolate with almost convex, less gibbous margins and broadly rounded ends (Figs 2529). Valve dimensions ( $n=10)$ : length $24-50 \mu \mathrm{m}$, valve width 10.0-14.0 $\mu \mathrm{m}$. Axial area rather broad, linear throughout most of its length, clearly widening to form a large, elliptic central area. First row of areolae not markedly separated from the rest of the striae. Raphe filiform, straight with clearly unilaterally bent to even hooked, long proximal raphe, completing their course entirely within the large central area, even within the smallest specimens. Distal raphe endings clearly deflected. Striae near the central area almost not more spaced than the other striae and clearly radiate whereas the other striae more distant from the central area only slightly radiate, gradually becoming parallel near the apices, $18-20$ in $10 \mu \mathrm{m}$. Areolae clearly discernible in LM, ca. 15-20 in $10 \mu \mathrm{m}$.

Scanning electron microscopy (Fig. 30): Striae composed of large, rounded to transapically elongated, oval areolae. The smallest areolae present near the central area. Proximal raphe endings sometimes asymmetrically bent with one hooked and one simply bent. Distal raphe endings deflected, bifurcated due to the presence of a large siliceous flap. Presence of canal puncta unclear due to possible confusion with normal areolae.

Holotype (designated here): BR-4352 (National Botanic Garden, Meise, Belgium)

Isotypes (designated here): PLP-246 (University of Antwerp, Belgium), BRM-ZU9/39 (Hustedt Collection, Bremerhaven, Germany)

Type locality: Byers Peninsula, Livingston Island, South Shetland Islands, sample LIV-BY16A (Leg. M. Toro; coll. date 16/12/2006).

Etymology: The species is named after Dr. Teresa Noga (Institute of Botany, Krakow, Poland) who found the species also on King George Island.

Ecology and distribution: Muelleria nogae is a rare species found so far only on Livingston Island and on King George Island (Teresa NogA, pers. comm.). The largest population was found in sample LIV-BY16A, taken from a biofilm in an area flooded by fresh water between stones on Byers Peninsula close to the main plateau. The sample is dominated by various taxa of Luticola, Hantzschia, Pinnularia and Diadesmis.

Taxonomic remarks: Muelleria nogae can hardly be confused with any other Muelleria species known so far, based on the unique, large central area. Muelleria bachmannii (Hustedt) S.A.Spaulding et StOERMER shows a somewhat similar valve outline with a somewhat enlarged central area but the latter area never reaches the same size and shape as in M. nogae (SPAULDING et al. 1999, Fig. 67). Other Muelleria taxa with a comparable gibbous valve center such as the 
more narrow $M$. meridionalis differ sufficiently not to be mistaken for $M$. nogae.

\section{Muelleria spauldingiana sp. nov. (Figs 31-40)}

Light microscopy (Figs 31-38): Valves linearlanceolate with convex margins and clearly capitate, broadly rounded apices. Valve dimensions $(n=8)$ : length 38-50 $\mu \mathrm{m}$, width $8.5-9.5 \mu \mathrm{m}$. Axial area rather narrow, linear, only very slightly widening towards the very small central area. First row of areolae bordering the axial area separated from the striae by a narrow hyaline line. Raphe filiform and straight. Proximal raphe endings unilaterally bent, relatively long, terminating before the first row of areolae, never extending into the first row. Distal raphe endings deflected to the same side as the proximal endings. Striae near the central area (4-5 striae) more spaced than the other striae and clearly radiate whereas other striae more distant from the central area only slightly radiate, gradually becoming parallel and even weakly convergent near the apices. Central striae 13-15 in 10 $\mu \mathrm{m}$, distal striae $19-21$ in $10 \mu \mathrm{m}$. Striae rather coarse, areolae discernible in LM, 18-20 in $10 \mu \mathrm{m}$.

Scanning electron microscopy (Figs 39-40): Striae composed of irregularly (c- and e-) shaped areolae throughout the entire valve. Largest and most complex areolae present near the axial area, gradually becoming smaller and more rounded towards the valve margins (Fig. 39). Areolae on mantle showing similar irregular shape (Fig. 40). Proximal raphe endings bent, terminating before the first row of areolae. Distal raphe endings bifurcating due to a large siliceous flap. One large canal punctum present near distal raphe endings (Fig. 40). Due to the rarity of this taxon, no observations of the valve interior could be made.

Holotype (designated here): BR-4353 (National Botanic Garden, Meise, Belgium)

Isotypes (designated here): PLP-247 (University of Antwerp, Belgium), BRM-ZU9/40 (Hustedt Collection, Bremerhaven, Germany)

Type locality: Byers Peninsula, Livingston Island, South Shetland Islands, sample BY052 (Leg. B. Van de Vijver; coll. date 15/01/2009).

Etymology: The species is named after our colleague Dr. Sarah A. Spaulding (INSTAAR, Boulder, Colorado, USA) in recognition of her contributions to Antarctic diatom research in general and the genus Muelleria more specifically.

Ecology and distribution: Muelleria spauldingiana is a very rare species, occasionally observed in very low numbers in some lakes of Livingston Island (South Shetland Islands). The largest population was found in a large lake between Midge and Limnopolar Lake on the central plateau of Byers Peninsula (although only a few valves were found). The lake is characterized by a slightly alkaline $\mathrm{pH}$ (7.35) and low specific conductance values $\left(<100 \mu \mathrm{S} . \mathrm{cm}^{-1}\right)$.

Taxonomic remarks: There are hardly any Muelleria species that show a similar valve outline as present in $M$. spauldingiana. The most similar taxon seems to be $M$. peraustralis (W. et G.S.WeSt) S.A.Spaulding et Stoermer, described in 1911 from the Antarctic Continent (West \& West 1911, Spaulding \& Stoermer 1997; VAN DE VIJVER et al. 2012). Both species can however be separated based on the shape of the areolae, being slit-like in $M$. peraustralis but very irregular, even e-shaped in $M$. spauldingiana. Moreover, $M$. spauldingiana has more capitate apices compared to the subcapitate apices in M. peraustralis. Muelleria bachmannii also shows a comparable valve outline but has very small, rounded areolae (VAN DE VIJVER, pers. obs.). Muelleria meridionalis is smaller with less elongated valves, non-bifurcating distal raphe endings and small, slit-like areolae. All other Muelleria species lack the typical capitate apices, coarse striation pattern and irregularly shaped areolae, justifying the description of M. spauldingiana as a new species.

\section{Muelleria subsabbei sp. nov. (Figs 41-51)}

Light microscopy (Figs 41-50): Valves strictly lanceolate with non-protracted, broadly rounded, apices. Valve dimensions $(\mathrm{n}=20)$ : length $18-27 \mu \mathrm{m}$, width 5.5-6.9 $\mu \mathrm{m}$. Axial area moderately broad, linear, widening to form a small, elliptic central area. First row of areolae bordering the axial area separated from the striae by a narrow hyaline line. Raphe filiform and straight. Proximal raphe endings short, unilaterally bent, terminating before the first row of areolae. Distal raphe endings deflected to the same side as the proximal endings. Striae near the central area (4-5 striae) more spaced than the other striae and clearly radiate whereas other striae more distant from the central area only slightly radiate, gradually becoming parallel and even weakly convergent near the apices. Central striae ca. 18 in $10 \mu \mathrm{m}$, distal striae $26-28$ in $10 \mu \mathrm{m}$. Striae rather coarse, areolae usually but not always discernible in LM.

Scanning electron microscopy (Fig. 51): Striae composed of very fine, transapically elongated slit-like areolae throughout the entire valve. Areolae bordering the axial area sometimes irregularly shaped, separated by hyaline zone from the rest of the striae. Proximal raphe endings bent, terminating before the first row of areolae. Distal raphe endings not bifurcating, strongly hooked onto the valve face extending into the first row of areolae, never continuing onto the mantle. One large canal punctum present near distal raphe endings. Due to the rarity of this taxon, no observations of the valve interior could be made.

Holotype (designated here): BR-4354 (National Botanic Garden, Meise, Belgium) 
Isotypes (designated here): PLP-248 (University of Antwerp, Belgium), BRM-ZU9/41 (Hustedt Collection, Bremerhaven, Germany)

Type locality: Byers Peninsula, Livingston Island, South Shetland Islands, sample LIV-BY16C (Leg. M. Toro; coll. date 16/12/2006).

Etymology: The specific epithet refers to the resemblance to Muelleria sabbei VAN DE VIJVER et S.A.SPAULDING but showing lower valve dimensions.

Ecology and distribution: Muelleria subsabbei is a rare species found so far only in two samples on Livingston Island. The largest population was found in sample LIV-BY16C, taken between stones from a biofilm in a seepage area flooded by fresh water on Byers Peninsula close to the main plateau. The sample is dominated by various taxa of Luticola, Hantzschia, Pinnularia and Diadesmis.

Taxonomic remarks: Muelleria subsabbei is up to now the smallest Muelleria species observed. Other small Muelleria species such as M. kristinae VAN DE VIJVER show a different pattern of the central striae (lacking any differentiation with the rest of the striae, different distal raphe endings (never continuing onto the valve face) and different valve outlines (linearlanceolate with acutely rounded ends compared to the strictly lanceolate valves with broadly rounded ends in M. subsabbei) (VAN DE VIJVER et al. 2010). Muelleria terrestris (Petersen) S.A.Spaulding et StOermer has more linear valves with longer proximal raphe endings. Unfortunately, SEM images for the latter species are lacking making a comparison on the distal raphe endings and the shape of the areolae impossible. Muelleria sabbei is much larger with clearly convex, rounded margins but shows comparable distal raphe endings terminating on the valve face, hence the nomenclatural connection between both species.

\section{Muelleria undulatoides sp. nov. (Figs 52-61)}

Light microscopy (Figs 52-60): Valves strictly linear with parallel but clearly undulated margins and almost non-protracted to weakly subcapitate (never rostrate), broadly rounded apices. Valve dimensions $(n=10)$ : length 23-29 $\mu \mathrm{m}$, width 6.0-7.5 $\mu \mathrm{m}$. Axial area narrow, linear, slightly widening forming a small, elliptic central area. First row of areolae bordering the axial area usually not separated from the striae by a narrow hyaline line, although valves with larger areolae near the axial area were observed. Raphe filiform, straight. Proximal raphe endings short, unilaterally bent, terminating before the first row of areolae. Distal raphe endings deflected to the same side as the proximal endings. Striae near the central area (6-8 striae) very slightly more spaced than the other striae and clearly radiate whereas other striae more distant from the central area only slightly radiate, parallel in the lower
$1 / 3$ of the valve and even weakly convergent near the apices. Central striae 18-20 in $10 \mu \mathrm{m}$, distal striae 23-26 in $10 \mu \mathrm{m}$. Striae rather coarse, areolae usually discernible in LM.

Scanning electron microscopy (Fig. 61): Only one eroded valve observed. Striae composed of small, rounded areolae. Areolae of the central striae smaller. Presence of canal puncta unclear. Proximal raphe endings clearly deflected, terminating before the first row of areolae. Distal raphe endings not bifurcating, continuing onto the valve mantle.

Holotype (designated here): BR-4355 (National Botanic Garden, Meise, Belgium)

Isotypes (designated here): PLP-249 (University of Antwerp, Belgium), BRM-ZU9/42 (Hustedt Collection, Bremerhaven, Germany)

Type locality: Hurd Peninsula, Livingston Island, sample 5-1/05 (Leg. R. Zidarova; coll. date 08/01/2005).

Etymology: The specific epithet refers to the undulated valve outline of the valves. It was deliberately chosen not to use the epithet 'undulata' to avoid confusion with Navicula gibbula var. undulata KRASSKE.

Ecology and distribution: So far the species has only been found in very low numbers in between mosses covered with thin cyanobacterial mats, collected on the shore of a small pool on Hurd Peninsula, Livingston Island, South Shetland Islands.

Taxonomic remarks: Actually, there is only a handful of Muelleria species showing an undulated valve outline. Kolbe (1959) discusses the morphology of Navicula lagerstedtii CLEVE but shows valves that represented a different taxon, later described as $N$. dubitanda. Therefore, several years later, HustedT \& Kolbe described in 1961 Navicula dubitanda (in 1997 later transferred to Muelleria by SPAULDING et STOERMER) but the illustrated valves show a species which is much bigger (up to $52 \mu \mathrm{m}$ ) with very narrow apices contrary to M. undulatoides that is smaller and has broadly rounded apices (HuSTEDT 1961). Navicula gibbula var. undulata, described in 1938 from Iceland, has a similar valve outline with undulated margins (KRASSKE 1938). Only 2 specimens could be identified from this species (LANGe-Bertalot et al. 1996, plate 17, figs. 25, 25). Based on the illustrations, the latter taxon apparently has a finer striation pattern, compared to the coarse striae in M. undulatoides. Moreover, the overall valve shape appears more slender and less compacted as is the case in $M$. undulatoides. Therefore, we exclude conspecificity between both taxa despite the lack of a detailed SEM analysis between both taxa. Muelleria holmenii (Foged) S.A.Spaulding et StOERMER, described from Peary Land, Greenland (Foged 1955), is also only known from a few specimens (SPAULDING et al. 1999). Based on the illustrated valves in SPAULDING 
et al. (1999, figs 4, 5), the latter can be separated from $M$. undulatoides by the narrower rostrate apices, compared to the more subcapitate, broadly rounded apices in the new species. Other taxa showing a similar valve outline are up to now not known. Taxa such as M. supra or M. meridionalis are sufficiently different based on their gibbous central part and the differences in the raphe structure to avoid all confusion (SPAULDING et al. 1999; Esposito et al. 2008).

\section{ACKnowledgements}

Samples on Byers Peninsula (Livingston Island) were taken in the framework of the IPY-Limnopolar Project POL2006-06635 (Ministerio de Ciencia y Tecnología, Spain). Samples on Hurd Peninsula (Livingston Island) were taken with the logistic support of the Bulgarian Antarctic Institute. The authors would also like to thank the members of expeditions to the Czech J.G. Mendel Antarctic Station for their support and help in the field. This study has been supported as a long-term research development project no. RVO 67985939. Mrs. K. Kopalová benefitted from an Erasmus grant during her stay in Belgium and GA UK grant nr. 394211. Part of the research was funded within the BELSPO CCAMBIO project (Belgium) and by L'Oréal-Unesco For Women in Science Program (Bulgaria)

\section{REFERENCES}

Cholnoky, B.J. (1955): Diatomeen aus salzhaltigen Binnengewässern der westlichen Kaap-Provinz in Südafrika. - Berichte der Deutschen Botanischen Gesellschaft 63: 11-23.

Cleve, P.T. (1894): Synopsis of the naviculoid diatoms. -Kongliga Svenska Vetenskaps-Akademiens Handlingar 26: 1-194.

EsPosito, R.M.M.; SPAulding, S.A.; McKnight, D.M.; VAN DE ViJVER, B.; Kopalová, K.; Lubinski, D.; Hall, B. \& Whittaker, T. (2008): Inland diatoms from the McMurdo Dry Valleys and James Ross Island, Antarctica. - Botany 86: 1378-1392.

Fermani, P.; Mataloni, G. \& Van de Vijver, B. (2007): Soil microalgal communities on an Antarctic active volcano (Deception Island, South Shetlands). - Polar Biology 30: 1381-1393.

Foged, N. (1955): Diatoms from Peary Land, North Greenland. Meddelelser om Grønland 147: 1-86.

Frenguelli, J. (1945): El Platense y sus diatomeas. - Revista del Museo de La Plata, Séccion Paleontologia no.16 3: 77-221.

Hamilton, P.B.; de HaAn, M.; Kopalová, K.; Zidarova, R. \& Van de ViJver, B. (2013): An evaluation of selected Neidium species from the Sub-Antarctic Region. - Diatom Research (in press) http://dx.doi.org/10.1080/0269249X.2013.822020

HENDEY, N.I. (1964): An introductory account of the smaller algae of British coastal waters. Part V. Bacillariophyceae (Diatoms) $-317 p p+44$ plates. , London: her Majesty's Stationery Office.

Hustedt, F. (1961-1966): Die Kieselalgen Dutschlands, Österreichs unde der Schweiz mit Berücksicht der übrigen Länder Europas sowie der Angrenzenden Meeresgebiete. - In: Dr. Rabenhorst Kryptogamen Flora von Deutschland, Österreich und der Schweiz 7(3): 1-815.

Kolbe, R.W. (1959): Zur Taxonomie von Navicula lagerstedtii Cl. Svensk Botanisk Todskrift 53: 64-70.

KopalovÁ, K. \& VAN DE ViJver, B. (2013): Structure and ecology of freshwater diatom communities of Byers Peninsula (Livingston Island, South Shetland Islands). - Antarctic Science 25: 239-253.

Kopalová, K.; NedBalová, L.; NÝvlt, D.; Elster, J. \& VAn de ViJVer, B. (2013): Ecological assessment of the freshwater diatom communities from Ulu Peninsula (James Ross Island, NE
Antarctic Peninsula). - Polar Biology 36: 933-948.

Krasske, G. (1938): Beiträge zur Kenntnis der Diatomeen-Vegetation von Island un Spitzbergen. - Archiv für Hydrobiologie 33: 503-533.

Krasske, G. (1949): Subfossile Diatomeen aus den Mooren Patagoniens und Feuerland. - Annales Academiae Scientiarum Fennicae Series A IV. Biologica 14: 3-94.

Lange-Bertalot, H.; Külbs, K.; Lauser, T.; Nörpel-Schempr, M. \& Willmann, M. (1996): Diatom taxa introduced by Georg Krasske. Documentation and Revision. - Iconographia Diatomologica 3: 1-358.

Lange-Bertalot, H. \& Genkal, S. (1999): Diatoms from Siberia I. - Iconographia Diatomologica 6: 1-271.

McCAll, D. (1933): Diatoms (recent and fossil) of the Tay District. - Journal of the Linnean Society of London, Botany 49: 219-308.

MüLler, O. (1909): Bacillariaceen aus Süd-Patagonien. Beiblatt zu den Botanischen Jahrbüchern. - Botani-sche Jahrbücher für Systematik, Pflanzengeschichte und Pflanzengeographie 43: $1-40$.

Østrup, E. (1910): Diatoms from North-East Greenland. Danmark Ekspedition til Grønlands Nordost, 1906-1908. Meddelelser om Grønland 43: 195-254.

Petersen, J.B. (1915): Studier over Danske aèrofile alger. - Det Kongelige Danske Videnskabernes Selskabs Skrifter, 7. Raekke, Naturvidenskabelig og Mathematisk 12: 269-380.

REICHARDT, E. (2004): Eine bermerkenswerte Diatomeenassoziation in einem Quellhabitat im Grazer Bergland, Österreich. Iconographia Diatomologica 13: 419-479.

Round F.E., Crawford R.M. \& Mann D.G. (1990): The diatoms. Biology \& Morphology of the genera. - 747 pp., Cambridge University Press, Cambridge.

Spaulding, S.A. \& Stoermer, E.F. (1997) Taxonomy and distribution of the genus Muelleria Frenguelli. - Diatom Research 12: 95-115.

Spaulding, S.A.; Kociolek, J.P. \& Wong, D. (1999) A taxonomic and systematic revision of the genus Muelleria (Bacillariophyta). - Phycologia 38(4): 314-341.

Van de Vijver, B.; Mataloni, G.; Stanish, L. \& Spaulding S.A. (2010): New and interesting species of the genus Muelleria (Bacillariophyta) from the Antarctic Region and South Africa. - Phycologia 49: 22-41

VAN DER WERFF, A. (1955): A new method for cleaning and concentrating diatoms and other organisms. - Verhandlungen der Internationalen Vereinigung für theoretische und angewandte Limnologie 12: 276-277.

Van de Vijver, B.; Tavernier, I.; Kellogg, T.B.; Gibson, J.A.; Verleyen, E.; Vyverman, W. \& Sabbe, K. (2012): Revision of the Antarctic diatom species (Bacillariophyta) described by West \& West (1911) with the description of two new species. - Fottea 12: 149-169.

West, W. \& West, G.S. (1911): Freshwater algae. - British Antarctic Expedition (1907-1909) Science Report, Biology 1: 263298.

ZidARova, R. (2008): Algae from Livingston Island (S Shetland Islands): a check-list. - Phytologia Balcanica 14: 19-35.

(C) Czech Phycological Society (2014)

Received November 11, 2013

Accepted December 13, 2013 